DOI: 10.46340/eujem.2020.6.2.18

\author{
Nicole Danilova, PhD in Economics \\ ORCID ID: https://orcid.org/0000-0002-2399-1578 \\ Taras Shevchenko National University of Kyiv, Ukraine \\ Yuliia Kuznetsova \\ ORCID ID: https://orcid.org/0000-0003-0513-7519 \\ Taras Shevchenko National University of Kyiv, Ukraine \\ MARKET ANALYSIS INSTRUMENTS \\ IN THE DEVELOPMENT OF THE STARTUP \\ MARKETING STRATEGY
}

The most common instruments for marketing analysis are considered in the paper to develop a successful startup marketing strategy. The choice of the most effective tool for analyzing the macro-, micro- marketing environment and internal environment of company/organization depends on market geography, industry, size of the company, resources, market type, life cycle of the market / product, etc. The paper systematizes the traditional marketing tools for strategy creation and justifies the possibility of their use in building up a startup viable business model. The specifics of the venture investor-consumer are identified. The authors' approach to the summarization of marketing strategy tools is proposed, and each cluster is considered with appropriate management concepts and models. The importance of marketing strategy for startups in the uncertain conditions has been explained and proven.

Keywords: marketing research, macromarketing environment, micromarketing environment, marketing strategy, startup, marketing tools, business model.

Research Justification. Many of the world's most valuable companies had humble beginnings as startups. In the olden days, it was extremely difficult to create a large and successful business without a tremendous amount of capital to open a factory or buy a fleet of trading vessels, for instance. As a result, new startups pop up every day all around the world, each of them hoping to get acquired by a larger company or make it big in their own right. However, for every wildly successful startup, there are thousands which fall into obscurity, which is why startups valued at a billion dollars or more are facetiously referred to as "unicorns", a reference to their elusiveness. However, more than $50 \%$ of investment projects do not succeed due to the lack of a clear project development strategy, a diverse professional team, underdeveloped soft skills, lack of a step-by-step plan for attracting and using investment, lack of a comprehensive system of marketing analysis. In order to solve a number of management problems and attract the necessary amount of investment, it is advisable to conduct a comprehensive marketing research, taking into account the macro, micro and intra-corporate environment, using marketing tools in accordance with the analysis of each component.

According to CBInsights, among the top 20 reasons for a startup failure, the first (42\%) is the lack of market demand, the second is the lack of funds $(29 \%)^{1}$. This is why startup marketing strategy is a topic of a current concern, and marketing tools can change the perception of the venture business to more effectively engage with stakeholders and profits generation. Startups start to fail when they do not meet the challenges of the market and cannot solve a market problem, as this should be a big enough problem that can be solved with an easily scalable product. The success of startups depends not only on financial support, but also on quality marketing research, information resources, as well as material and manpower resources, which can all be obtained in a timely manner with the help of marketing planning.

There are many tools for marketing analysis in the modern theory and practice of marketing, however, they are not systematized, are not popularized and / or have a weak descriptive nature. In Ukraine, there is still a weak culture of using marketing services and using marketing tools, especially in the startup ecosystem.

${ }^{1}$ CBInsights (2019). The Top 20 Reasons Startups Fail <https://www.cbinsights.com/research/startup-failure-reasons-top/> (2020, March, 11). 
Purpose of the Paper. The purpose of the article is to research, systematize and popularize comprehensive marketing research tools to optimize the process of developing a startup feasible strategy.

\section{Main Material}

Marketing strategy is a crucial element in the enterprise management system, the market dictates the rules in the conditions of constantly increasing competition, skyrocketing customer fastidiousness and the emergence of new forces that affect the company. The majority of strategy-making models emerged in the last 40-50 years and was initially focused on certain aspects of marketing. An exception - the AIDA model, which was created in the 1900s, all the others began to appear after Teodor Levitt's doctrine on the basic principles of marketing.

Scientists who were among the first to start studying marketing strategy issue and management concepts: M. Porter, I. Ansoff, A. Maslow, N. Kano, P. Kotler, C. Rogers, H. Mintzberg, L. Greiner, E. de Bono, D. Kahneman. All tools alone only provide information in a specific context, so different analytical tools are rational to be used to create a viable marketing strategy.

The main objective of the marketing strategy is to make products meet the consumer, satisfying the latter's needs, but profitably for the stsrtup. And models, in turn, are toolkits that allow you to structure approaches to finding solutions to the management problems that a startup faces.

Models such as SWOT analysis, PEST analysis, and Porter's five forces are used to shape the overall strategy. Models that deals with competitive advantage: four Porter angles, Porter's overall strategies, and USP analysis. Models that allow you to develop marketing strategies include customer journey mapping, Maslow's pyramid of needs, the Rogers diffusion curve, and the 4P, 5P, 7P marketing mix concepts, and so on. It is important to understand that models cannot be used mechanically; all models require adaptation to a specific company or strategic business unit, as they can be also applied to startups.

Trying to create a general algorithm for building a marketing strategy, the first step will be to determine the place of the startup in the ecosystem today - the state of it:

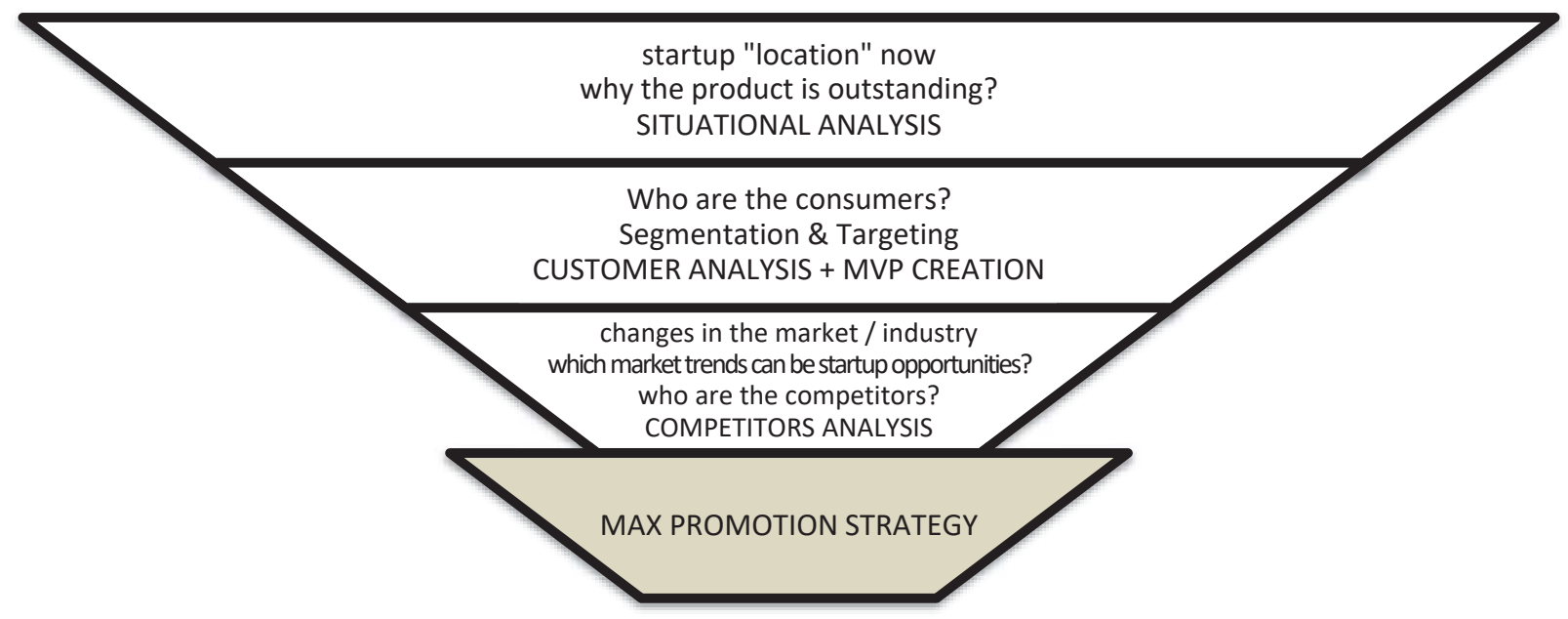

Fig. 1. Key elements in developing a startup marketing strategy

Source: Compiled by the authors on the basis of previous researches

As far as a business model of venture startup often has three obvious characteristics: firstly, this business model must have a high-quality unit economy, so the price of a product or service must far outweigh the cost; secondly, this business model must be scaleable quickly; thirdly, this business model should have "built-in" protection from competitors. It is easy to see that turnover, profit and therefore the value of such a startup will grow rapidly.

In this case situational / management analysis allows to identify trends, opportunities, threats and success factors that shape the environment of the startup. In the first phase, you can use tools, like PEST analysis, SWOT analysis, or Porter's five forces to systematize and identify industry trends that may affect a business. Porter's five forces model will help to identify who is more powerful in a particular market: a company, suppliers, consumers, or competitors. 
In the process of analyzing the macromarketing environment, companies use different tools, depending on the industry in which the company operates, location of activity, company size, product life cycle stage, etc. A characteristic feature of a macromarketing environment research is that all market factors that are changing dynamically affect the market, in general, and the startup, in particular, are subject to analysis, but the company generally does not have a direct influence on the factors of the macromarketing environment (except merging companies of one industry into core business associations that intend to lobby for members' interests and thus influence the functioning of the market; in the case of startup projects clusters - lobbying is done by influencing the environment through business angels, venture funds and other investors).

On the path of researching modern world literature, the following tools were identified to analyze the external market environment (Table 1): PEST / ETPS / STEP, PESTEL, PESTELI, STEEP, STEEPLED, LEPEST, PESTLE, LoNGPESTEL, ETOP, SWOT, methodology of prof. A. Starostina. Such a number of tools used in marketing practice, described in theoretical studies of national and foreign scientists, means that there is no single universal tool for analyzing the market environment of the company.

Table 1

Summarizing Table of Marketing Analysis Tools

\begin{tabular}{|c|c|c|}
\hline Environment & Shared Instruments & Specific Instruments \\
\hline $\begin{array}{l}\text { Macromarketing } \\
\text { Environment }\end{array}$ & \multirow{3}{*}{$\begin{array}{c}\text { SWOT, ETOP } \\
\text { SPACE, Delphi } \\
\text { Technique, Lifecycle } \\
\text { Model, BCG Matrix }\end{array}$} & $\begin{array}{l}\text { PEST / ETPS / STEP, PESTEL / PESTLE / } \\
\text { LEPEST, PESTELI, PESTLIED, SLEPT / } \\
\text { STEEP / STEEPLE / STEEPLED, } \\
\text { DESTEP, LoNGPESTEL / LONGPESTLE } \\
\text { A. Starostina methodology }\end{array}$ \\
\hline $\begin{array}{l}\text { Micromarketing } \\
\text { Environment }\end{array}$ & & $\begin{array}{l}\text { SNW, ABC-analysis, Mc Kinsey 7S, } 2 \times 2 \\
\text { matrix Ansoff's, PIMS, } 5 \text { PORTER'S, } \\
\text { SIMALTO, 4P, 5P, 7P, 5C, 15C, 18P, } \\
\text { AIDA, SAVE, AIDAS }\end{array}$ \\
\hline $\begin{array}{l}\text { Internal corporate } \\
\text { environment }\end{array}$ & & $\begin{array}{l}\text { VRIO, USP, SOSTAC, MOSAIC, } \\
\text { SERVQUAL, RATER, mystery shopper }\end{array}$ \\
\hline
\end{tabular}

Source: compiled by authors

Different approaches to analyze the macromarketing environment were identified:

PEST-Analysis / ETPS / STEP - a market analysis tool by which an organization examines external uncontrollable factors of the market environment (political, economic, social, technological) in order to improve its competitive position in the market. It was first introduced into the economic categorical apparatus by Harvard professor Francis J. Aguilar in 1967 and evolved over the course of marketing theory and practice $^{1}$.

PESTEL / PESTLE / LEPEST - a tool used by marketers to analyze and monitor environmental factors (political, economic, social, technological, environmental, legal) that affect an organization ${ }^{2}$.

PESTELI (Market, Economic, Social, Technological, Environmental, Legal and International Issues and Implications) is a market analysis tool through which an organization investigates external uncontrollable factors of a market environment: political, economic, social, technological, environmental, legal and international issues, and consequences ${ }^{3}$.

\footnotetext{
${ }^{1}$ Kenton, W. (2020). PEST Analysis. Investopedia <https://www.investopedia.com/terms/p/pest-analysis.asp $>$ (2020, March, 11).

${ }^{2}$ Harvard Referencing Blog (2020). Marketing Theories - PESTEL analysis. Professional Academy.

$<$ https://www.professionalacademy.com/blogs-and-advice/marketing-theories---pestel-analysis > (2020, March, 11).

${ }^{3}$ Shone, A., Parry, B. (2013). Successful Event Management. London: Cengage.
} 
PESTLIED (PEST / LIED) is an analysis tool through which an organization examines the factors of the business environment, including political, economic, social, technological, legislative, international, natural, demographic ${ }^{1}$.

SLEPT is an analysis tool by which an organization examines factors of the business environment, including social, legislative, economic, political, technological ${ }^{2}$.

STEEP and STEEPLE is an analysis tool through which an organization examines the factors of the business environment, including: social, technological, economic, natural, political, legislative, ethical ${ }^{3}$.

STEEPLED is an analysis tool through which an organization examines the factors of the business environment, including: social, technological, educational, ethical, political, legislative, economic, demographic ${ }^{4}$.

DESTEP is an analysis tool through which an organization examines external factors of the business environment, including: demographic, economic, socio-cultural, technological, environmental, political ${ }^{5}$.

It can be concluded that all of the above tools for analyzing the external environment of the company are a complement to the classic PEST tool (Table 2).

Table 2

PEST-analysis Evolution

\begin{tabular}{|c|c|c|c|c|c|c|c|c|c|}
\hline Instrument & 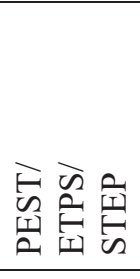 & 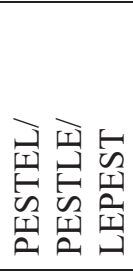 & 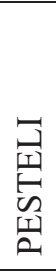 & 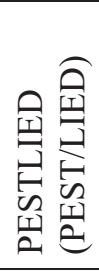 & $\frac{5}{\sqrt[5]{5}}$ & 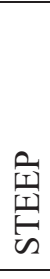 & 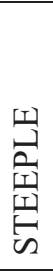 & 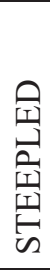 & 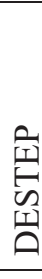 \\
\hline Political & + & + & + & + & + & + & + & + & + \\
\hline Economic & + & + & + & + & + & + & + & + & + \\
\hline Social & + & + & + & + & + & + & + & + & \\
\hline Technological & + & + & + & + & + & + & + & + & + \\
\hline Environmental & & + & + & + & & + & + & & \\
\hline Legal & & + & + & + & + & & + & + & \\
\hline International issues and implications & & & + & + & & & & & \\
\hline Demographic & & & & + & & & & + & + \\
\hline Ethic(al) & & & & & & & + & + & \\
\hline Education & & & & & & & & + & \\
\hline Socio-cultural & & & & & & & & & + \\
\hline Ecologic(al) & & & & & & & & & + \\
\hline
\end{tabular}

Source: compiled by authors

The evolution of this tool is driven by the objective reality of changing business opportunities with the intensification of the impact of globalization and internationalization.

${ }^{1}$ Yarnold, D. (2020). PEST/LIED. Alchemy Assistant.

$<$ https://www.alchemyassistant.com/topics/6V4rAwvEpNpRBKvR.html> (2020, March, 11).

${ }^{2}$ By Business Case Studies (2019). Slept-analysis <https://businesscasestudies.co.uk/slept-analysis/> (2020, March, 11).

${ }^{3}$ PESTLE analysis Contributor (2015). Difference between STEEP and STEEPLE Analysis.

$<$ https://pestleanalysis.com/steep-and-steeple-analysis/> (2020, March, 11).

${ }^{4}$ Miller, S. (2010). STEEPLED Analysis Made Easy. Ezinearticles $<$ https://ezinearticles.com/expert/Sam_Miller/77981> (2020, March, 11).

${ }^{5}$ De Vlieger, R. (2012). DESTEP analysis. Calltheone $<$ https://www.calltheone.com/en/business-coaches/destep-analysis $>$ (2020, March, 11). 
Recent additions to the PEST analysis tool include the LoNGPESTLE / LONGPESTEL which analyses Political, Economic, Social, Technical, Legal and Environmental groups of factors on Local, National, Global markets.

Table 3

LoNGPESTLE - analysis Elements

\begin{tabular}{|l|l|l|l|l|l|l|}
\hline \multicolumn{1}{|c|}{ Market } & Political & Economic & Social & Technological & Legal & Environmental \\
\hline Local & & & & & & \\
\hline National & & & & & & \\
\hline Global & & & & & & \\
\hline
\end{tabular}

Source: compiled by authors based on ${ }^{1}$

The structure of the instrument allows to classify political, economic, social, technical, legal and environmental factors depending on the location of the company activity: in local, national and global markets $^{2}$.

ETOP (Environmental Threat \& Opportunities Profile) is a management tool that analyzes the external environment of an organization and determines the relative impact of threats and opportunities for systematic assessment of the market environment.

Table 4

ETOP-analysis Elements

\begin{tabular}{|l|l|l|}
\hline \multicolumn{1}{|c|}{ Environmental sector } & \multicolumn{1}{c|}{ Nature of impact } & \multicolumn{1}{c|}{ Impact of the sector (examples) } \\
\hline Economic & $\uparrow$ & Rising incomes, burgeoning middle class \\
\hline Market & $\rightarrow$ & Several major players, lots of small players \\
\hline Global & $\downarrow$ & Global slowdown, cheaper global; prices \\
\hline Politic & $\downarrow$ & Instability, soon elections \\
\hline Regulatory & $\rightarrow$ & Huge governmental control, standards \\
\hline Social & $\uparrow$ & Changing attitudes, new social trends \\
\hline Technology & $\uparrow$ & Technology development level \\
\hline Suppliers & $\rightarrow$ & Too few vendors, new suppliers, pricing \\
\hline
\end{tabular}

Source: compiled by authors based on $^{3}$

The research of external environmental factors is seen as the process of gathering, analyzing and using of information for tactical or strategic purposes. The ETOP process involves the distribution of environmental factors into different groups of factors, as well as an analysis of the impact of each group of factors on an organization's activities. ETOP gives a clear picture of each group of business environment factors, individual grouping factors that affect the business favorably or are evaluated negatively or neutrally ${ }^{4}, 5$.

SWOT (Strength, Weakness, Opportunity, Threat) is a summary analysis of the strengths, weaknesses of the organization, the opportunities and threats of the market under research, which is the basis for assessing the competitive position of the startup and developing strategic planning (Table 5).

\footnotetext{
${ }^{1}$ Lucidity Strategy Platform (2020). Introduction to LoNGPESTLE Analysis < https://getlucidity.com/strategy-resources/ introduction-to-longpestle-analysis $>$ (2020, March, 11).

${ }^{2}$ Ibid.

${ }^{3}$ LessonForBusiness (2020). Business Management Lesson. Environmental Threat \& Opportunities Profile $($ ETOP). $<$ http://lessonforbusiness.blogspot.com/p/environmental-threat-opportunities.html> (2020, March, 11). ${ }^{4}$ Ibid.

${ }^{5}$ Studiousguy (2020). Techniques of Environmental Scanning $<$ https://studiousguy.com/techniques-of-environmentalscanning/> (2020, March, 11).
} 
SWOT -analysis Elements

\begin{tabular}{|c|c|c|c|}
\hline \multirow{3}{*}{ 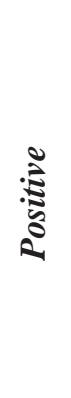 } & & & \multirow{3}{*}{ 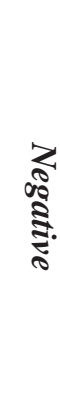 } \\
\hline & $\begin{array}{c}\text { Strength } \\
\text { (company's advantages) }\end{array}$ & $\begin{array}{c}\text { Weaknesses } \\
\text { (areas to improve) }\end{array}$ & \\
\hline & $\begin{array}{l}\text { Opportunities } \\
\text { (external factors that help company } \\
\text { to grow or get strength) }\end{array}$ & $\begin{array}{l}\text { Threats } \\
\text { (external factors that are risky } \\
\text { for a company) }\end{array}$ & \\
\hline
\end{tabular}

Source: compiled by authors based on ${ }^{1}$

SWOT analysis assesses internal and external factors, as well as current and future potential for development directions ${ }^{2}$ and enables the visualization of the results of the macro- and micromarketing environment research.

Thus, in order to analyze the factors of the macromarketing environment, companies choose and adapt the tools that are most effective for market geography, industry, size of the company, resources, market type, life cycle of the market / product, etc., which is of particular importance in the process of market research for startups.

SWOT analysis is one of the most well-known models for identifying the strategic direction of the company's development, an important component of the model is brainstorming. To use this tool, you need to set limits: by specific brand / company, target audience, product group, geographic region. A model was created at the Stanford Institute in 1960 under the direction of Albert Humphrey. In the first model instead of weaknesses and strengths were: "satisfactory" and "fault". And in 1964, the model took on its present form. Example of the use can be seen in the Table 6.

VRIO analysis should also be added in the first step, if it is necessary to determine the potential and efficiency of the resources owned by the startup, which include both physical assets and processes. In the VRIO model, "valuable" resources are those that affect the company's financial performance - help reduce costs, increase revenue, or ideally do both. A resource is considered "rare" if no one, or very few, have access to it. "Genuine" - the notion of "rarity" a step further - rare resources cannot be imitated or copied easily, and that there are few substitutes. It is possible to valuable, rare or unique resources if there is no idea how to use them in full - or "organize" - this is the last component of this model.

So it is crucial to focus startup internal management systems, business processes, and people's time and energy on utilizing these resources to maximize their value to startup as a whole. Also, to think long term so that it can be protected and improved key resources for the future. VRIO analysis helps to evaluate how startup's resources are contributing to the market position.

Resources that are very valuable, rare, unique, and organized to use will contribute most to the position in the market, so be sure to nurture and use them to the fullest.

The 4P (product, place, price, promotion) concept or other modifications can be used when designing a marketing program or in analyzing a business situation, especially when launching a new product or entering a new market. The $4 \mathrm{P}$ concept is about promoting the right product in the right place at the right time, that is, helping to form a marketing complex.

The following questions can be asked to determine if a product is marketed: solves?

-What will the customer receive from the product, what are the benefits and problems that this product

-Which customers are the most likely buyers? How can they be described as a segment?

- How do customers use the product? How often? When to replace?

\footnotetext{
${ }^{1}$ Grant, M. (2020). Strength, Weakness, Opportunity, and Threat (SWOT) Analysis. Investopedia.

$<$ https://www.investopedia.com/terms/s/swot.asp > (2020, March, 11).

${ }^{2}$ Grant, M. (2020). Strength, Weakness, Opportunity, and Threat (SWOT) Analysis. Investopedia.

$<$ https://www.investopedia.com/terms/s/swot.asp > (2020, March, 11).
} 
SWOT -analysis Examples

\begin{tabular}{|c|c|c|}
\hline & 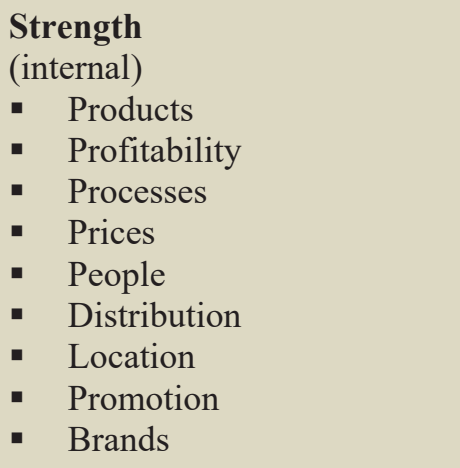 & $\begin{array}{l}\text { Weakness } \\
\text { (internal) } \\
\text { - } \text { Products } \\
\text { - } \text { Profitability } \\
\text { - } \text { Processes } \\
\text { - } \text { People } \\
\text { - } \text { Distribution } \\
\text { - } \text { Location } \\
\text { - } \text { Promotion } \\
\text { Brands }\end{array}$ \\
\hline $\begin{array}{l}\text { Opportunity } \\
\text { (external) } \\
\text { - Market size and growth } \\
\text { - Target Audience } \\
\text { - Competitiveness } \\
\text { - Technology } \\
\text { - Economy } \\
\text { - Politics } \\
\text { - External environment } \\
\text { - Legislation } \\
\text { - Trends and Fashion }\end{array}$ & $\begin{array}{l}\text { Clear priorities } \\
\text { They are easily and quickly } \\
\text { implemented }\end{array}$ & $\begin{array}{c}\text { Hard options } \\
\text { There may be a problem } \\
\text { with the changes and resources } \\
\text { required }\end{array}$ \\
\hline $\begin{array}{l}\text { Threat } \\
\text { (external) }\end{array}$ & $\begin{array}{l}\text { Aspects to be taken } \\
\text { into consideration to protect } \\
\text { the company }\end{array}$ & $\begin{array}{l}\text { It is difficult to react, } \\
\text { but responding } \\
\text { can be overwhelming if } \\
\text { there is a threat to the company }\end{array}$ \\
\hline
\end{tabular}

Source: compiled by authors based on ${ }^{1}, 2$

\begin{tabular}{|c|c|}
\hline $\begin{array}{c}\text { Product } \\
\text { it's all about the offer - features and benefits }\end{array}$ & $\begin{array}{c}\text { Place } \\
\text { it is the channel through which the product } \\
\text { enters the market }\end{array}$ \\
\hline $\begin{array}{c}\text { Promotion } \\
\text { is a set of promotion tools used } \\
\text { to market a product }\end{array}$ & Price \\
(at each level in the value chain)
\end{tabular}

Fig. 2. The 4P marketing mix

Source: compiled by authors based on ${ }^{3}$

\footnotetext{
${ }^{1}$ Ibid.

${ }^{2}$ Businessballs (2020). SWOT analysis <https://www.businessballs.com/strategy-innovation> (2020, March, 11).

${ }^{3}$ Ettenson, R., Conrado, E., Knowles, J. (2013). Rethinking the 4Ps. Harvard Business Review, Jan-Feb. 
Price is the only component on which income depends, all others are expenses, revenue must be sufficient to make a profit.

Promotion tools inform the market and assure its value to the consumer - this is all about advertising, direct marketing, PR.

A place is a location where a product or service is available to a customer, it can be both an online resource and a manufacturer.

Mainly, the concept is concentrated at the target audience, these four main components are called "hygiene factors", because if marketing strategy should not be defeated, it must be taken into account. The following factors are often added to the basic model:

People who manufacture, deliver, sell, connect with a customer, serve.

Process - product manufacturing is a part of the offering, and there are processes in the company in customer relationships.

Physical is an important part of the offer, especially in supermarkets.

This concept has been criticized by Richard Ethenson, Jonathan Knowles and Edward Conradi in the Harvard Business Review in the context of B2B. After all, the McCarthy concept focuses on technology and product quality that do not provide differentiation. By shifting the emphasis from products to solutions, the concept of SAVE (solution, access, value, education) was formed: solution, not product - focusing on problem solving; access, not place - the importance of having access to clients for the benefit of the Internet; value, not price; education, not promotion - reputation and confidence that builds over time will be a more important factor in industrial markets for decision making.

AIDA (awareness, interest, desire, action) was developed by Frank Dusmit in 1904 and refined in 1921 by Russell, analyzes how to make marketing communications more effective, a model widely used in the advertising and promotion world to improve communications in four stages. Targets a specific target audience who is interested in purchasing a specific product. This is a sequential model where the proportion of people shrinks from level to level (see Figure).

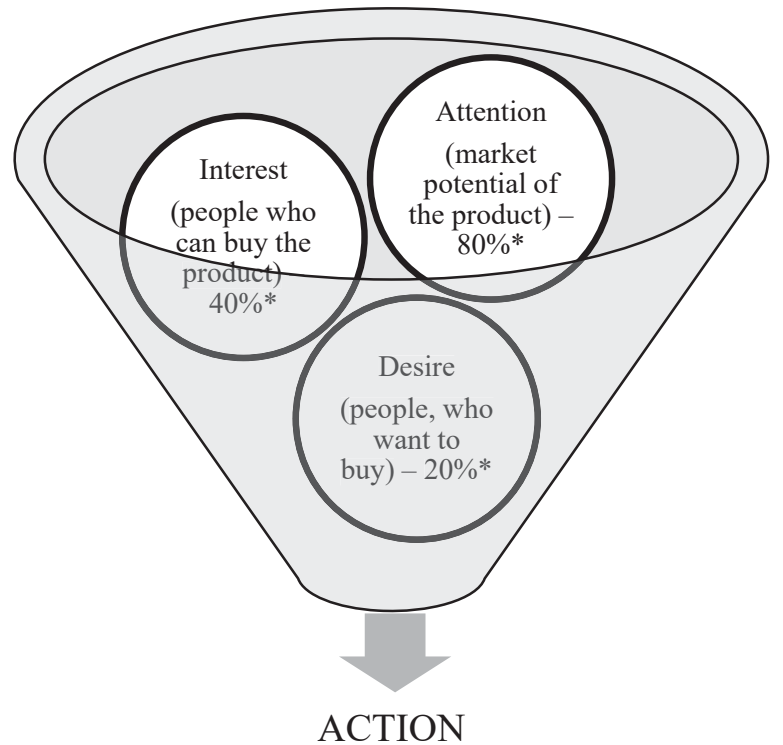

(customer, who buys the product) $10 \% *$

Fig. 3. AIDA-model

Source: compiled by authors based on ${ }^{1}$

* - percentage of total population (sampling)

\footnotetext{
${ }^{1}$ Helyer, R. (2015) The Work-Based Learning Student Handbook. London: Palgrave Macmillan.
} 
Attention - attention is the result of all effective communications, because if people do not know about the product, they cannot show interest in it, so this is a critical moment of all marketing campaigns. The tools that are selected for the campaign depend on the target audience and the product / service, usually a combination of different media. Usually, the advertising budget is formed on this principle - about $2 \%$ of the revenue, although this is not a fairly correct budgeting mechanism.

Interest - advertising should respond to the target audience, be relevant and offer what can satisfy needs and desires. The features and benefits of the product should be communicated in the language of the target audience for which a special value proposition should be formed.

Desire - effective advertising is not scattered and focuses on one or two parts of the value proposition that are most attractive to the potential buyer. At this stage, the buyer is likely to have alternatives with which to compare, but the final decision may be based on emotional or subjective factors.

An action can be either a purchase or a site visit or a request, depending on the purpose of the advertisement.

This model has also been refined into AIDAS (+ satisfaction) by Arthur Sheldon. But the goal remains unchanged - attracting attention, arousing interest, building confidence in the choice, and 8 out of 10 people read nothing but the headlines.

Boston Consulting Group Matrix - helps to plan your product portfolio or balance the operation of multiple strategic business units. Developed by a team of consultants led by Bruce Henderson in 1968-1970. It is used to strategically plan the performance of each product or subsidiary and to identify areas of investment concentration. It has two dimensions: the attractiveness of the market in terms of growth and the market share of each product relative to the largest competitor in the industry; and four quadrants: along the $\mathrm{X}$ axis - relative market share and along the $\mathrm{Y}$ axis growth. Accordingly, they distinguish:

Stars - upper right quadrant; it is a monopoly product or one that has a significant competitive advantage. Fast market growth means investment in production and stocks. These are almost always price leaders and can generate big profits.

Poor Dogs - lower left quadrant; the complete opposite of the stars is low share and low market growth. These are outdated products that in need of updating, but the market for such a product may be static or declining.

Cash cows - lower right quadrant; such products have strong competitive positions and generate profits, these are products that have reached maturity.

Question marks or problem children - left upper quadrant; these products have the ability to move to stars-products, but many products need to developed to maintain the number of stars, as most have short lives and are quickly replaced. The main feature is uncertainty.

Of course, the model has its drawbacks, for example, a company with a high market share in the growing market may not be profitable, if everything is spent to maintain positions, and with attractive growth rates - the product can quickly get substitutes in the market. The matrix is often combined with a lifecycle model to refine product perspectives (Figure). According to research, successful companies have in their portfolio at least $30 \%$ of products that are younger than 3 years.

It is important to keep in mind about a balanced portfolio while maintaining sufficient amount of question marks, recognizing that not all of them will become stars, but cash cows are a source of funding for future growth.

The McKinsey 7S model was developed in the late 1970s during a successful business strategy study, formed in 1980 by four McKinsey employees - Bob Waterman, Anthony Atos, Richard Pascal, Tom Peters. In their paper, two of them proved that this model is used by the Japanese. 7S (strategy, structure, system hard elements + staff, skills, style, shared values - soft elements) - to test the health of a company and support its sustainable development. Hard elements are easier to identify and management can directly influence them. The soft elements are more culture-related, so they are harder to identify, but they are not easily copied by competitors, here we refer to the VRIO model. All of these elements are interrelated, so changing one will affect the other elements as well (see Figure 5). 


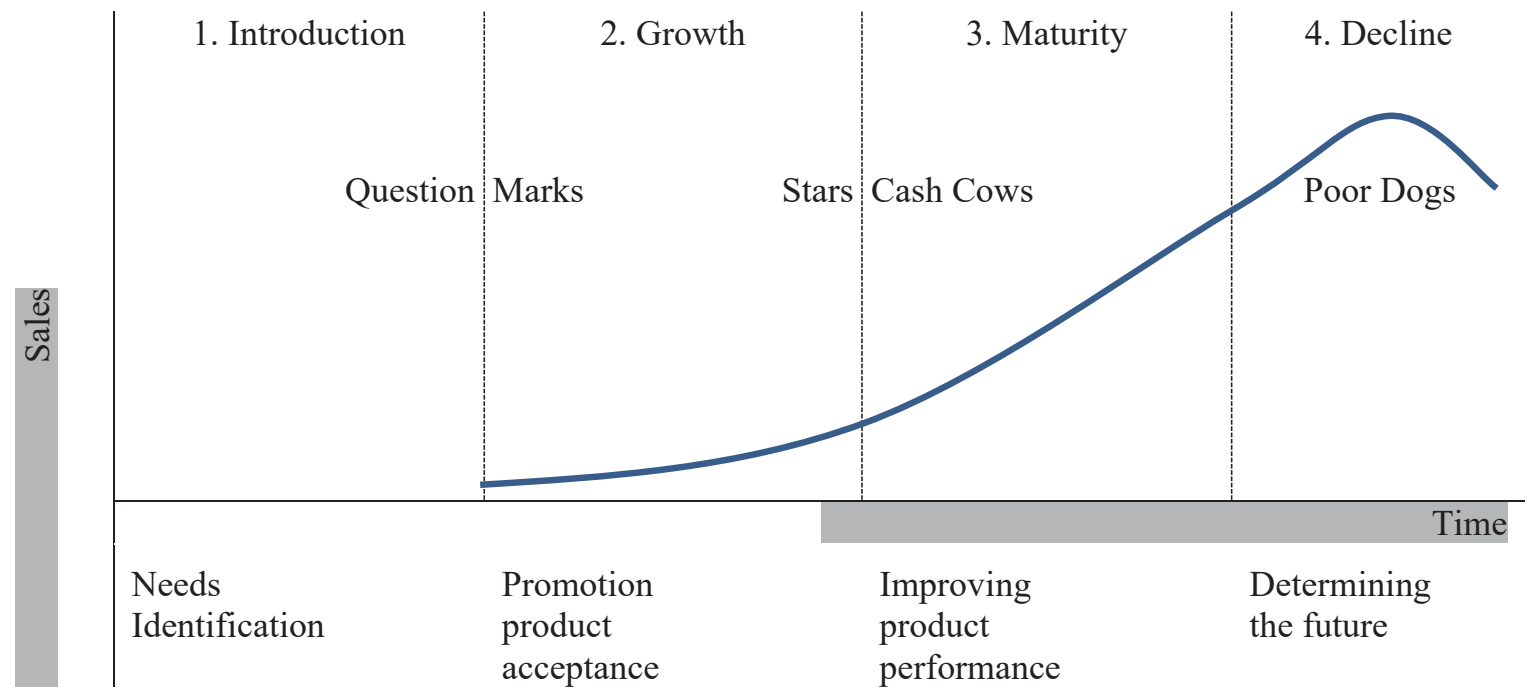

Fig. 4. Lifecycle model combined with the BCG matrix

Source: compiled by authors based on ${ }^{1}$

Strategy

- mid-term and long-term management growth plan for the startup

\section{Structure}

- mechanism for the relationship set up between elements of a company or its strategic business units

\section{System}

-processes of assessing the functioning of the company - IT system

\section{Shared Values}

- culture and DNA of the startup, these are the features of the company and its corporate culture

Style

- top management behaviors of the company that are influenced by the managerial style of the CEO

\section{Staff}

- workers, their numbers, methods of search and training, their affiliation

\section{Skills}

- core competencies of employees

\section{Fig. 5. 7S McKinsey Model}

Source: compiled by authors based on ${ }^{2}$

\footnotetext{
${ }^{1}$ Vernon, R. (1966) International Investment and International Trade in the Product Cycle. Quarterly Journal of Economics, 80 (2), 190-207.

${ }^{2}$ Tompeters (2020). A Brief History of the 7-S ('McKinsey 7-S') Model <http://tompeters.com> (2020, March, 11).
} 
Thus, the 7S model demonstrates where there is potential for improvement, is a structural corset of changes in the company, allows planning an approach to the implementation of the strategy, taking into account all available factors and their peculiarities, as well as streamlines processes and interaction between different structural units. This tool is useful for auditing a company, identifying its weaknesses and strengths, identifying elements that are not cooperated with others and which are needed to focus. It is a kind of modifier of SWOT analysis. But in practice, the seven is applied in five stages: the audit of the elements in order to harmonize them; determining what they should look like; determining what changes are needed; implementation of the plan; monitoring and analysis. All these elements should be analyzed in terms of how they help to meet the customer's need.

MOSAIC is a model that is an extension of standard business questions: Where are we? Where are we going? How to get there? This is an acronym that contains tools for solving macro and microprocess problems in a business: mapping, objectives, strategy, action, implementation, controls. It was developed by $2 \mathrm{~B}$ International in 1996 as a market research-driven action management tool.

\begin{tabular}{|c|c|}
\hline Mapping & $\begin{array}{l}\text { A tool that determines startup current position and possible directions: market } \\
\text { estimation }+ \text { future trends }+ \text { competitors }+ \text { position in the market }+ \text { price positions }\end{array}$ \\
\hline Objectives & SMART (specigic, measurable, achievable, realictis, time-bound) \\
\hline Strategy & $\begin{array}{l}\text { A long-term plan for achieving goals based on competitive advantage } \\
\text { and flexibility }\end{array}$ \\
\hline Action & Detailed action plan: tactics, people, resources, timing \\
\hline Implementation & $\begin{array}{l}\text { Process of updating a plan where optimism is tested by realities. } \\
\text { Who? What? When? How? }\end{array}$ \\
\hline Control System & $\begin{array}{l}\text { Indicators that measure the goals achievement - to solve problems } \\
\text { that have or may have arisen }\end{array}$ \\
\hline
\end{tabular}

Fig. 6. MOSAIC model

Source: compiled by authors based on B2B International, 1998

Together with this concept came the SOSTAC tool (Situation, Objectives, Strategy, Tactics, Action, Control) that was created by marketer Paul Smith to develop a marketing plan.

SOSTAC and MOSAIC are used to plan and make management decisions, making effective use of the tools previously discussed: PEST analysis and SWOT to understand the causal relationships at the mapping stage that takes time, but will provide the opportunity to form the strategy, goals and implementation plan which is the most hardstage with further difficulties.

How to relate customer expectations to company performance - SERVQUAL concept, the research outputs will identify where there are gaps between expectations and customer service provided. Three scientists were dissected: Parsu Parasuraman, Valari Zeitaml, and Len Berry as a result of a study in 1988, initially the model was more extensive.

The model is based on five dimensions of service: RATER (reliability; assurance; tangible factors, empathy, responsiveness).

Quality of service is estimated by the equation:

$\mathrm{P}($ level perception $)-\mathrm{E}$ (expectation) = quality of service

If there are gaps, then by concept, they are identified by the following:

- Knowledge gap: between management understanding and what clients really want to gain.

- Standards gap: between standards set by the company and what customers expect.

- Delivery gap: between customer expectations and what they receive.

- Communication gap: between promises and their fulfillment.

- Customer satisfaction gap: between customer satisfaction and their expectations. 
The model allows you to identify breaks and formulate a list of causes, as well as minimize breaks in the future, raising the level of service or not delivering unrealistic promises or improving staff skills or improving communication efficiency.

Typically, surveys are conducted in the form of ballot questionnaires, but they contain many questions, so they are not possible with via a phone. It's important to keep in mind that clients are becoming more demanding in their expectations.

SIMALTO (simultaneous multi-attribute level trade-off) was developed by market researcher John Green in 1977 and is popular with B2B market researchers, whose sampling is small but highly specialized. This model allows to consider 20 attributes. Helps marketers determine how effective the product is, whether it meets customer expectations, or what needs to be changed to make a customer want to pay for it. This concept acts as a "competitor" of joint analysis, which requires a large enough sampling, as opposed to "simultaneously balancing on attributes and levels." That is, in this model, to provide clients with a list of attributes and want to get their ranking in order of importance, and each attribute has its own levels, that is, the degree of implementation. The following table looks like - see Figure 7.

Table 7

SIMALTO-model

\begin{tabular}{|l|l|l|l|l|}
\hline \multicolumn{1}{|c|}{ Attribute } & \multicolumn{1}{c|}{ Level 1 } & \multicolumn{1}{c|}{ Level 2 } & \multicolumn{1}{c|}{ Level 3 } & \multicolumn{1}{c|}{ Level 4 } \\
\hline Attribute 1 & Weight (5) & Weight (10) & Weight (15) & Weight (20) \\
\hline Attribute 2 & Weight (5) & Weight (10) & Weight (15) & Weight (20) \\
\hline Attribute 3 & Weight (5) & Weight (10) & Weight (15) & Weight (20) \\
\hline Attribute 4 & Weight (10) & Weight (15) & Weight (20) & Weight (30) \\
\hline
\end{tabular}

Source: compiled by authors based on ${ }^{1}$

* Numbers in parentheses are a value for each level; can be modified if the cost of the upgrade is high enough in the product - as the last line

At the end of the survey, respondents were given a certain amount of points that needed to be divided down by attribute levels that are needed improvement, as the customer felt. Limiting the number of points leads to balance and indicates whether they are willing to pay for the modifications. Thus, this model does not require a large sample. This information can also serve as a basis for preparation for in-depth interviews. The sample should consist of different types of clients to be able to identify and segment based on the survey.

The greatest difficulty arises when designing the questionnaire / table, choosing the attributes to include, as well as describing the attribute levels - the language should be the clearest and as close as possible to the respondents.

USP-analysis - how to create a unique sales offer for a product or service. If a company does not have a unique product, then it constantly competes with similar offers in the market - that is why there is a USP to differentiate in the market of similar products. This should be complex with the target audience, the value proposition, the competitive situation and the production processes.

The concept emerged in the 1940s in advertising agencies and was formed by Ross Reeves, who sought triggers for the target audience that would also have a call to action, then USPs were implemented as slogans. The stages of creating a USP are represented in the Figure 7.

To use this tool, SWOT-analysis, mapping of the client's path, strategy of quality-price positioning of Kotler must be already considered:

In the process, it is needed to look for the aspect that matters most to startup customers and minimizes emotional barriers, and no one else competitor does so yet. It is imperative that the USP is tested and verified to match the brand position of the company.

The term "USP" has been almost replaced by the concept of a value proposition, which focuses on several aspects that customers are willing to pay for. El Rice and Jack Trout emphasize the importance of the connection between brand position and the statement of unique features of the startup; brand positioning has become more important than a single product.

\footnotetext{
${ }^{1}$ Smith, P.R. (2015) SOSTAC: The Guide to your Perfect Digital Marketing Plan. England: PR Smith.
} 


\begin{tabular}{|c|c|}
\hline 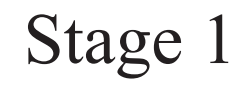 & $\begin{array}{l}\text { - Target Audience selection } \\
\text { - Who is the consumer? Their portrait }\end{array}$ \\
\hline & $\begin{array}{l}\text {-TA's needs identification } \\
\cdot \text { list even minor needs }\end{array}$ \\
\hline & $\begin{array}{l}\text {-identification of the unmet needs of the TA } \\
\text {-What do they want to get and what they don't get now? }\end{array}$ \\
\hline & $\begin{array}{l}\text { - ranking needs and unmet needs } \\
\text { - in descending order of weight }\end{array}$ \\
\hline & $\begin{array}{l}\text { - grouping all the elements of the value proposition } \\
\text { - consists of different advantages and qualities of product }+ \text { service }+ \text { support } \\
\text { - assessing importance for the customer }\end{array}$ \\
\hline & $\begin{array}{l}\text { - comparison with customer offers } \\
\text {-What is the difference? }\end{array}$ \\
\hline & $\begin{array}{l}\text { - analysis of product manufacturing processes } \\
\text { - material sources }+ \text { production methods }+ \text { control system } \\
\text { - What is outstanding / interesting for TA? }\end{array}$ \\
\hline ge 8 & $\begin{array}{l}\text { - selection of benefits, qualities, or stories that influence TA } \\
\text { - select an attribute that will be attractive to TA }\end{array}$ \\
\hline
\end{tabular}

Fig. 7. Algorithm to create feasible USP

\section{Source: compiled by authors based on ${ }^{1}$}

Finishing all these steps, it is possible to create startup model canva - startup market analysis data can now be used to implement viable marketing strategy in a startup business model and determine how a startup will sell products to whom and what volumes are potentially available. The last step will be to make sure that the startup can generate profits for the stakeholders.

The key threat is not to evaluate where sales are made and not to track the return on investment for marketing activity (ROMI). Startups nowadays have digital tools for fast, easy and cheap performance tracking, so monitoring and control are always the final steps in the strategy.

Conclusions and Recommendations. The most important issue for startup-projects is planning process of company's development. To make a high-qualified marketing research considering all factors, which influence the market, startups should choose the acceptable instrument depending on market geography, industry, size of the company, internal resources, market type, life cycle of the market or product, etc. Thus, all these steps will help the startup to develop a roadmap for selecting and implementing the changes that need to be made to enter new market or to attract investment. The algorithm solves the most common problems of unsuccessful launch from market-fit, end of funds, high competition, pricing problems, lack of business model, inefficient marketing, ignoring customers to disharmony in the team.

\section{References:}

1. Kenton, W. (2020). PEST Analysis. Investopedia <https://www.investopedia.com/terms/p/pest-analysis.asp $>$ (2020, March, 11). [in English].

2. Harvard Referencing Blog (2020). Marketing Theories - PESTEL analysis. Professional Academy.

$<$ https://www.professionalacademy.com/blogs-and-advice/marketing-theories---pestel-analysis $>$ (2020, March, 11). [in English].

3. Shone, A., Parry, B. (2013). Successful Event Management. London: Cengage.

4. Yarnold, D. (2020). PEST/LIED. Alchemy Assistant.

$<$ https://www.alchemyassistant.com/topics/6V4rAwvEpNpRBKvR.html > (2020, March, 11). [in English].

${ }^{1}$ McCarthy, E. J. (1960). Basic Marketing: A managerial Approach. Homewood, Illinois. 
5. By Business Case Studies (2019).Slept-analysis <https://businesscasestudies.co.uk/slept-analysis/> (2020, March, 11). [in English].

6. PESTLE analysis Contributor (2015). Difference between STEEP and STEEPLE Analysis. $<\mathrm{https}: / /$ pestleanalysis.com/steep-and-steeple-analysis/> (2020, March, 11). [in English].

7. Miller, S. (2010). STEEPLED Analysis Made Easy. Ezinearticles $<$ https://ezinearticles.com/expert/Sam_Miller/77981> (2020, March, 11). [in English].

8. De Vlieger, R. (2012). DESTEP analysis. Calltheone $<$ https://www.calltheone.com/en/business-coaches/destep-analysis $>$ (2020, March, 11). [in English].

9. Lucidity Strategy Platform (2020). Introduction to LoNGPESTLE Analysis <https://getlucidity.com/strategyresources/introduction-to-longpestle-analysis> (2020, March, 11). [in English].

10. LessonForBusiness (2020). Business Management Lesson. Environmental Threat \& Opportunities Profile $(E T O P),<\mathrm{http}: / /$ lessonforbusiness.blogspot.com/p/environmental-threat-opportunities.html $>$ (2020, March, 11). [in English].

11. Studiousguy (2020). Techniques of Environmental Scanning <https://studiousguy.com/techniques-ofenvironmental-scanning/> (2020, March, 11). [in English].

12. Éverton L., Elton J., Carlos R. (2014). Environmental Scanning, Strategic Behavior And Performance In Small Companies.. JISTEM J.Inf.Syst. Technol. Manag. vol.11 no.3 São Paulo Sept./Dec. 2014.

13. Grant, M. (2020). Strength, Weakness, Opportunity, and Threat (SWOT) Analysis. Investopedia. $<$ https://www.investopedia.com/terms/s/swot.asp> (2020, March, 11). [in English].

14. Helyer, R. (2015) The Work-Based Learning Student Handbook. Palgrave Macmillan, London.

15. Businessballs (2020). SWOT analysis <https://www.businessballs.com/strategy-innovation> (2020, March, 11). [in English].

16. McCarthy, E. J. (1960). Basic Marketing: A managerial Approach. Homewood, Illinois.

17. Ettenson, R., Conrado, E., Knowles, J. (2013). Rethinking the 4Ps. Harvard Business Review, Jan-Feb.

18. Lavidge, R. J. and Steiner, G. A. (1961). A model for predictive measurements of advertising effectiveness, Journal of Marketing, October, 25.

19. Henderson, B. (1970). The Product Portfolio. Boston Consulting Group.

20. Tompeters (2020). A Brief History of the 7-S ('McKinsey 7-S') Model <http://tompeters.com> (2020, March, 11). [in English].

21. Waterman, R. H., Peters, T. J. and Philips, J. R. (1980). Structure is not organization. Business Horizons, 23 (3), 14.

22. Smith, P. R. (2015). SOSTAC: The Guide to your Perfect Digital Marketing Plan. England: PR Smith.

23. Aguilar, F. J. (1967). Scanning the Business Environment. Macmillan, New York.

24. Vernon, R. (1966). International Investment and International Trade in the Product Cycle. Quarterly Journal of Economics, 80 (2), 190-207.

25. Parasuraman, A., Zeithaml, V.A., Berry, L. L. (1985). A conceptual model of service quality and its implications for future research. The Journal of Marketing, 49 (4), 41-50.

26. CBInsights (2019). The Top 20 Reasons Startups Fail <https://www.cbinsights.com/research/startup-failurereasons-top/> (2020, March, 11). [in English].

27. Crunchbase (2020). Platform for finding business information about private and public companies

$<$ https://www.crunchbase.com> (2020, March, 11). [in English]. 